\title{
Constitutionale
}

Volume 2 Issue 2, July-December 2021: PP: 115-124

Faculty of Law, Universitas Lampung, Bandar Lampung, Indonesia.

http://jurnal.fh.unila.ac.id/index.php/constitutionale

P-ISSN: 2723-2492 E-ISSN: 2745-9322

\section{Differences in the Arrangement of Leave Outside the State Responsibility for Presidential Candidates and Incumbent Regional Head Candidates Based on the Equality Before the Law}

\author{
Muhammad Hadiyan Rasyadi \\ Universitas Lampung, Indonesia \\ muhamadhadiyan@gmail.com
}

Submitted: Jun 23, 2021; Reviewed: Nov 24, 2021; Accepted: Dec 27, 2021

\begin{tabular}{ll}
\hline Article's Information & Abstract \\
\hline $\begin{array}{l}\text { keywords: Elections; Equality } \\
\text { Beofre the Law; Leave Outside } \\
\text { the state }\end{array}$ & $\begin{array}{l}\text { The existence of differences in leave arrangements outside } \\
\text { of the state's responsibility for incumbent candidates in } \\
\text { the Presidential and Vice Presidential Election (pilpres) }\end{array}$ \\
DOI & $\begin{array}{l}\text { and the General Election of Regional Heads and Deputy } \\
\text { Regional Heads (pemilukada) have an impact on the sense }\end{array}$ \\
https://doi.org/10.25041/constit & of justice in granting political rights attached to citizens. \\
utionale.v2i2.2357 & The research describes the arrangements differences \\
& from the equality before the law's perspective. The type of \\
& research used is normative legal research with descriptive \\
& legal research methods. The problem approach used is \\
statutory, comparative, and conceptual approaches. The \\
data used in this research is secondary data, with a \\
literature study method. \\
Furthermore, the technique used in this research is to \\
collect, identify and analyze the data presented in a \\
qualitative descriptive form. The results of the research \\
and discussion show that there are differences in leave \\
arrangements outside of the state's responsibility for \\
presidential and vice-presidential candidates and \\
incumbent regional heads and deputy regional heads in \\
the presidential and regional elections. Theoretically, \\
every legislation formulation and application must be \\
based on the principle of equality before as a form of \\
social justice.
\end{tabular}




\section{A. Introduction}

For incumbents, political rights to be elected as government leaders or representatives of the people. Especially in terms of the nomination and election of President and Vice President and Regional Heads. The problem in question is related to the obligation of the incumbent candidate to take leave outside the state's responsibility to avoid abuse of state facilities attached to his position.

The incumbent is a political term often used in elections and post-conflict local elections. Etymologically the incumbent is the one who is holding the position. ${ }^{1}$ In the Kompas language column, the term incumbent as a political term outside the legal term in legislation was popularized by Solomon Simanungkalit on February 6, 2009, as the equivalent of an incumbent and is synonymous with another newly formed word, namely petakhta. Compare it with survive, which means "to reside, sit". In other terms, by default, as the holder of a particular political position (currently or still in office). ${ }^{2}$ While the term incumbent is not regulated in the legislation, the term incumbent in statutory regulations can be interpreted as being in articles regarding elections as election participants or regional elections who are individuals holding the same position to be re-elected. The right of the incumbent is a political right that an individual can take with the limitation of being able to be elected in one period only. This is the result of the 1945 Constitution of the Republic of Indonesia's first amendment.

Leave outside the state's responsibility is a right that state officials cannot carry out their obligations within the time specified based on the applicable laws and regulations. This is done to avoid abuse of authority and facilities of state officials. However, in implementing the presidential or regional elections, leaving outside the state's responsibility is an obligation carried out during the campaign period.

Two different laws regulate the provision of non-state leave for incumbent candidates. The rules for leaving the state's responsibility for incumbent presidential election candidates are regulated in Article 281 Paragraph (1) letter b of Law Number 7 of 2017 concerning Elections. This regulation regulates election campaigns that include Regional Heads, and Deputy Regional Heads must fulfil the conditions for taking leave outside the state responsibility. There are specific exceptions for incumbent candidates in the presidential election, regulated in Article 301 of Law Number 7 of 2017 concerning Elections. The regulation stated that the President or Vice President designated as a participant in the presidential election could conduct a campaign by taking into account the duties of the government.

The leave outside the state's responsibility for incumbent candidates in the regional election's rules does not have exceptions as in the presidential election. Moreover, the arrangement is regulated in Article 70 Paragraph (3), letter b of Law Number 10 of 2016 concerning the Regional Head General Election, which regulates Regional Heads and Deputy Regional Heads who re-nominate in the regions. At the same time, must take leave outside the state's responsibility.

Based on the Constitutional Court's decision Number 10/PUU-XVII/2019, the fair elections principle in Article 22E of the 1945 Constitution of the Republic of Indonesia is related to the incumbent Presidential and Vice President candidate. Therefore, restrictions are imposed on them to create an equal treatment with pairs of presidential candidates and other

\footnotetext{
${ }^{1}$ Great Dictionary of Indonesian Language KBBI, “Arti Petahana,” Lektur.id, 2019, https://lektur.id/arti-petahana. 2 Great Dictionary of Indonesian Language, KBBI, "Petahana," Kemendikbud.go.id, 2019, https://kbbi.kemendikbud.go.id/entri/Petahana.
} 
vice presidential candidates who are not incumbents who do not have access to state facilities. ${ }^{3}$ This principle is implemented in Article 301 by considering Article 7 of the 1945 Constitution of the Republic of Indonesia, namely the term of office of the President and Vice President, which must be five years in one term of office. Based on this provision, it is interpreted that the article is a closed norm that allows special rights to be granted to candidates for President and Vice President who are incumbent. In reading the verdict, it was concluded that the incumbent presidential and vice-presidential candidates do not need to leave outside the state's responsibility.

In this research, the author will use a historical and comparative approach to examine the substantive issues of the legal issues discussed more deeply. These legal issues formulate problems from this background, namely, how to compare the arrangements for leave outside dependents between the presidential and vice-presidential candidates and regional head candidates with incumbents. Furthermore, how is applying the principle of equality before the law?

\section{B. Discussion}

1. Comparison of Leave Arrangements for Non-State Dependents Between President and Vice President Candidates with Regional Heads and Incumbent Deputy Regional Heads Candidates

The existing laws and regulations have explained in great detail the types of elections in the regional election, after the amendments to the 1945 Constitution of the Republic of Indonesia, in particular article 18 paragraph (4), states Governors, Regents and Mayors respectively as heads of Provincial, Regency and Democratically elected cities. ${ }^{4}$ Since the enactment of Law Number 32 of 2004 concerning Regional Government, it has emphasized that the electoral system in the regional election is a direct election. At the same time, this law overrides and abolishes the indirect election system contained in Law Number 22 of 1999 concerning Regional Government. ${ }^{5}$

In the Constitutional Court Number 10/PUU-XVII/2019 decision, the "fair" principle as stated in Article 22E of the 1945 Constitution of the Republic of Indonesia is implemented in Article 301 by considering Article 7 of the 1945 Constitution of the Republic of Indonesia. The principle applies to the President and Vice President, which must undergo five years in a governing period. In that provision, it is interpreted that the article is a closed norm that allows special rights to be granted to candidates for President and Vice President who are incumbent. In reading the verdict, it is concluded that the incumbent presidential and vice-presidential candidates do not need to take leave outside the state's responsibility. ${ }^{6}$

Referring to the ius constitutum in the Indonesian constitution, the President and vice president's constitutionality in Indonesia has been regulated in Article 7 of the 1945 Constitution of the Republic of Indonesia. However, the formulation of the article still has weaknesses. Namely, first, this article has a formulation that opens a gap to be interpreted differently from the original intent of the formulation of the article. When referring to Article 7 of the 1945 Constitution of the Republic of Indonesia, the President and vice president limits

\footnotetext{
3 Michael Buehler, Ronnie Nataatmadja, and Iqra Anugrah, "Limitations to Subnational Authoritarianism: Indonesian Local Government Head Elections in Comparative Perspective," Regional \& Federal Studies 31, no. 3 (2021): 381-404, https://doi.org/10.1080/13597566.2021.1918388.

${ }^{4}$ Eko Sabar Prihatin, "Politik Hukum Otonomi Daerah Tentang Pemilukada," Masalah-Masalah Hukum 43, no. 1 (2014): 49-56, https://doi.org/10.14710/mmh.43.1.2014.49-56.

5 Al Fajar Nugraha and Atika Mulyandari, "Pilkada Langsung Dan Pilkada Tidak Langsung Dalam Perspektif Fikih Siyasah," Mazahib: Jurnal Pemikiran Hukum Islam 15, no. 2 (2016): 208-37, https://doi.org/10.21093/mj.v15i2.630.

${ }^{6}$ Michael Buehler and Ronnie Nataatmadja, "A Research Agenda for Studying Legislative Incumbent Turnover in New Democracies, Using Indonesia as a Case Study," South East Asia Research 27, no. 3 (2019): 203-24, https://doi.org/10.1080/0967828X.2019.1642027.
} 
are intended to be enforced either successively or not successively. The most important thing is that after serving two terms of office, he is permanently unable to serve the same position again in the office. ${ }^{7}$

The difference in the arrangement of leaves outside the state's responsibility in the implementation of the presidential and regional elections has not been able to answer the problems of organizing elections which can be generalized as follows: ${ }^{8}$
a. $\quad$ Stealing campaign start
b. money politics
c. public officials' involvement in election campaigns
d. government facilities and accommodation related to positions' use
e. vote counting fraud

From some of the points above, it can be seen that there are two problems in the different arrangements for leave outside the state's responsibility for incumbent candidates, namely the involvement of public officials in the presidential election campaign and the use of government facilities and facilities related to positions. This can happen because there are still regulations that allow the President with his position as head of state and head of government to carry out campaigns by considering the implementation of his duties and obligations as President.

The problems and successes refer to the election as a result of the direct election process used in the regional election process. There are at least two parameters or indicators of the democratic election process. First, the provisions that regulate every stage of the implementation of elections contain legal certainty (predictable procedures), ${ }^{9}$ Namely,

(1) does not contain a legal vacuum,

(2) between consistent provisions (not contradictory), and

(3) does not contain provisions that have multiple interpretations. Second, the provisions governing each stage of the implementation of elections are formulated based on the principles of democratic elections (direct, general, free, confidential, honest, fair, accountable, educative). ${ }^{10}$

A legal loophole has been highlighted in this particular arrangement for the incumbent. The incumbent has prepared himself long before his opponents by using the government's work program as a campaign tool directly or indirectly. In this case, deviations from the implementation of the work program can occur, which can be used as a covert campaign. The incumbent's consequence can carry out a permanent campaign. ${ }^{11}$

The discussion regarding these restrictions has already been discussed in the changes to the 2008 regional election law, namely by discussing leave outside the state responsibility for regional heads and incumbent regional deputy regional heads. The incumbent Regional Head and Deputy Regional Head candidates are obliged to leave outside the state's responsibility. Thus, this can minimize the abuse of authority of the incumbent Regional Head and Deputy

\footnotetext{
${ }^{7}$ Qonita Dina Latansa, "Konstitusionalitas Batasan Masa Jabatan Presiden Dan Wakil Presiden Di Indonesia," Jurist-Diction 2, no. 2 (2019): 595, https://doi.org/10.20473/jd.v2i2.14254.

${ }^{8}$ Surya Kusuma Wardana, "Pemilihan Umum Sebagai Sarana Mewujudkan Pemerintahan Yang Bersih, Baik, Dan Berwibawa," Seminar Nasional Hukum Universitas Negeri Semarang 4, no. 3 (2018): 738, https://doi.org/http://journal.unnes.ac.id/sju/index.php/snh/article/view/27098.

${ }^{9}$ Edward Aspinall and Marcus Mietzner, "Indonesia's Democratic Paradox: Competitive Elections amidst Rising Illiberalism," Bulletin of Indonesian Economic Studies 55, no. 3 (2019): 295-317, https://doi.org/10.1080/00074918.2019.1690412.

${ }^{10}$ Fitriyah, "Meninjau Ulang Sistem Pilkada Langsung: Masukan Untuk Pilkada Langsung Berkualitas," Politika: Jurnal Ilmu Politik 2, no. 1 (2013): 40-47, https://doi.org/10.14710/politika.2.1.2011.40-47.

${ }^{11}$ Diego Fossati, "A Tale of Three Cities: Electoral Accountability in Indonesian Local Politics," Journal of Contemporary Asia 48, no. 1 (2018): 23-49, https://doi.org/10.1080/00472336.2017.1376345.
} 
Regional Head candidates to steal campaign starts, take advantage of state facilities and government funds, and use ASN as a covert success team. ${ }^{12}$

The discussion on leave outside of the state's responsibility aligns with the incumbent Presidential and Vice-Presidential candidates' historical arrangements changes concerning the Amendment to Article 7 of the 1945 Constitution of the Republic of Indonesia. ${ }^{13}$ Election of President and Vice President. The incumbent can be elected in one office. This is undoubtedly a limitation on selecting the President and Vice President during the old order, which served 32 years. Most importantly, the oligarchy of power is one of the factors that cause President Soeharto to be re-elected every year. This means that the spirit that arises is not just to cut the 32-year term, but the spirit that arises in reform is to break the oligarchic chain by utilizing all state equipment in holding power. Therefore, it is necessary to generalize the arrangements regarding leave outside the state's responsibility in the presidential and regional elections.

In addition, historically, the debate regarding the obligation of the incumbent regional head candidate to take leave from his position during the regional election campaign is not something new. The debate has surfaced in the public sphere since the Constitutional Court's Decision Number 17/PUU-VI/2008. The Constitutional Court's decision was born from the review of Law Number 32 of 2004 concerning Regional Government and Law Number 12 of 2008 concerning the Second Amendment to Law Number 32 of $2004 .{ }^{14}$

\section{The Equality Before the Law's Principle's Implementation in Leave Arrangements Outside of State Responsibility Comparison between President and Vice President Candidate and Regional Heads and Incumbent Deputy Regional Heads Candidate}

State and law are two different entities but are closely related. The state can be seen as a community-building in which it requires law. Law is a condition sine qua non for the state. The state and law cannot be separated because the state needs law. Therefore, the state can also be seen as a legal entity. Furthermore, the state is nothing but the embodiment of the legal order of a nation..$^{15}$

Furthermore, the concept of the rule of law in Article 1 Paragraph (1) of the 1945 Constitution of the Republic of Indonesia is a democratic legal state (democratische rechtstaat) and, at the same time, a democratic state based on the law (constitutional democracy) which is inseparable from one another ${ }^{16}$ Likewise, the concept of human rights cannot be separated from the existence of a state of law that indeed prioritizes and protects human rights. Therefore, speaking of the rule of law, of course, it is impossible to miss the discussion on human rights. ${ }^{17}$ Starting from this conception, the concept of equality before the law implements the rule of law concept.

The concept of equality in Pancasila as a state philosophy refers to social justice, where social justice is relegated to the norms in the 1945 Constitution of the Republic of Indonesia.

\footnotetext{
12 J. Kaloh, Kepemimpinan Kepala Daerah: Pola Kegiatan, Kekuasaan, Dan Perilaku Kepala Daerah Dalam Pelaksanaan Otonomi Daerah (Jakarta: Sinar Grafika, 2009).

13 Mahkamah Konstitusi Republik Indonesia, Naskah Komprehensif Perubahan UUD NRI 1945, (Buku IV Kekuasaan Pemerintah Negara Jilid 1, Revisi (Jakarta: Mahkamah Konstitusi Republik Indonesia, 2010), https://www.mkri.id/public/content/infoumum/naskahkomprehensif/pdf/naskah_Naskah Komprehensif Buku 4 Jilid 1.pdf.

${ }^{14}$ Muhammad Rudi Juanda, "Konstruksi Hukum Wajib Cuti Bagi Petahana Kepala Daerah Berdasarkan Putusan Mahkamah Konstitusi Nomor 60/PUU-XIV/2016," Jurnal Ilmu Hukum Riau 8, no. 5 (2019): 51-69, https://jih.ejournal.unri.ac.id/index.php/JIH/article/view/6038.

${ }^{15}$ Budiyono Budiyono and Siti Khoiriah, Negara Hukum Dan Demokrasi, 1st ed. (Bandar Lampung: Zam-Zam Towers, 2017).

16 Zulkarnain Ridlwan, "Negara Hukum Indonesia Kebalikan Nachtwachterstaat," FIAT JUSTISIA:Jurnal Ilmu Hukum 5, no. 2 (2014): 141-52, https://doi.org/10.25041/fiatjustisia.v5no2.56.

17 Fauzan Khairazi, "Implementasi Demokrasi Dan Hak Asasi Manusia Di Indonesia," Inovatif: Jurnal Ilmu Hukum 8, no. 1 (2015): 72-94, https://online-journal.unja.ac.id/jimih/article/view/2194.
} 
To dissect social justice broadly, ten essential elements parse social justice: One is about equality before the law. ${ }^{18}$

1. Institutions are not ends but means. (Politics are subordinate to ethics),

2. Common goods cannot be opposed to individual goods, not individuals set up against the common goods. A right improves duties and is one term of a moral relation),

3. Moral freedom,

4. Social and political freedom,

5. Equality,

6. Personal justice,

7. Equal pay for equal service,

8. The assignment of property should be conceived to secure freedom for the individual and power for the community,

9. Social and personal factors in wealth,

10. Democracy,

In this discussion, there are two essential points from the above theory. The first is about political freedom and equality and equality. As an essential factor in supporting social justice, constitutional rights cannot be separated from the study of differences in leave arrangements outside the state's responsibility for presidential and vice-presidential candidates and incumbent regional heads and regional deputy regional heads in the political process, namely the presidential election and post-conflict local election. From the differences regarding leave that is not borne by the incumbent candidate in the presidential and regional elections, we should analyze the comparison based on the principle of equality before the law. The difference of leave rights and obligations outside of the state's responsibility's grants between presidential election regulation and regional election needs to be analyzed. This matter is also applied towards the incumbent, in this case, the President and the Regional Head position.

Article 27 Paragraph (1) of the 1945 Constitution of the Republic of Indonesia is one of the acknowledgements and affirmations of human rights in the legal and political fields. ${ }^{19}$ Article 27 Paragraph (1) of the 1945 Constitution of the Republic of Indonesia is one of the acknowledgements and affirmations of human rights in the legal and political fields. Human rights in the political field affirm political emancipation, which means that every citizen has the same position in political life. Every citizen is a political person with no difference between one and another. There are no privileges or special rights of a person or group of people in political life. ${ }^{20}$

The general description of this principle in the International Encyclopedia of the Social Science suggests that humans are the same, only based on their characteristics humans have differences. In the Equality theory, human equality can be divided into four parts: ${ }^{21}$

1. Natural equality: similarities that are brought and born owned by humans. Humans are the same because all humans have the same ratio that distinguishes them from animals as God's creations.

2. Civil equality: equal civil rights for every citizen. For example, everyone has equal rights before the law without discrimination.

3. Political equality: equal rights in politics. This means that everyone has the same opportunity to vote and be elected, enter political parties and elections.

\footnotetext{
18 Jimly Asshiddiqie, Konstitusi Keadilan Sosial : Serial Gagasan Konstitusi Sosial Negara Kesejahteraan Sosial Indonesia (Jakarta: Penerbit Buku Kompas, 2018).

${ }^{19}$ Ali Sadikin, Tantangan Demokrasi (Jakarta: Pustaka Sinar Harapan, 1995).

${ }^{20}$ Sadikin.

${ }^{21}$ Eka N.A.M. Sihombing, "Mendorong Pembentukan Peraturan Daerah Tentang Bantuan Hukum Di Provinsi Sumatera Utara," Jurnal Rechts Vinding: Media Pembinaan Hukum Nasional 2, no. 1 (2013): 81, https://doi.org/10.33331/rechtsvinding.v2i1.83.
} 
4. Economic equality: equality of opportunity in improving the economic standard. The economic rights of citizens are the same and are protected by the constitution.

Regarding this theory, the difference in the arrangement of leaves outside the state's responsibility towards candidates for President and Vice President and incumbent Regional Heads and Deputy Regional Heads are concerned with political equality as outlined in-laws and regulations. In political equality, it returns to Article 28D Paragraph (3) of the 1945 Constitution of the Republic of Indonesia as the basis for the formation of laws and regulations governing the presidential election and regional election.

In implementing political equality based on the 1945 Constitution of the Republic of Indonesia, everything returns to social justice, which is the norm contained in Pancasila as the basic norm (grund norm) in the formation of legislation in Indonesia. The values contained in it determine the validity of all positive legal systems, in case all laws and regulations must be sourced from the values of Pancasila. ${ }^{22}$ So in the constitutional concept of social justice, there are four concepts: distributive justice, procedural justice, retributive justice, and restorative justice. In the distributive justice's concept, distributive justice consists of criteria, namely:

a. Equity, which means that the reward for a person must be equal to his contribution to society.

b. Equality means that everyone gets an equal share, regardless of input or contribution.

c. Necessity is the essential criteria for division based on needs.

Furthermore, what is explained in procedural justice (procedural justice) depends on the recipient's point of view of the distribution of justice. If he feels that what is received is equivalence, they accept it by comparing what others receive. Namun, jika hal tersebut dirasa tidak berkeadilan, ia akan menempuh keadilan restoratif and/or retributive justice. Then retributive justice works based on imposing sanctions that retaliate for violating norms. At the same time, restorative justice is the opposite of retributive justice, where the final result is improved unfair actions. ${ }^{23}$

This application is very concerned about equality in applying rights to citizens. The citizens' rights are regulated in Article 28 Paragraph (3) of the 1945 Constitution of the Republic of Indonesia to vote and be elected without discrimination. In principle, every democratic country contains human rights guarantees, including civil and political rights of every person or resident in the state constitution. However, everything depends on the authorities' political will to provide space for these civil and political rights. Parties need to prevent acts of oppression or restraint on implementing civil and political rights for every person or citizen residing in the country. ${ }^{24}$

From the discussion above, we can relate the application of leave arrangements outside the state's responsibility to the principle of equality before the law. There is a different application between the provisions contained in the Election Law and the Regional Head Election Law in the application of incumbent candidates, and when viewed from the concept of equality in distributive justice (distribution of justice) that whatever level of position a citizen gets the same rights beyond his contribution. This application views equality in the application of rights to citizens. The law as a legal product must return to the legal objectives expressed by Gustav Radbruch, namely justice (gerechtigkeit), expediency (zweckmassigkeit) and legal certainty (rechtssicherheit). ${ }^{25}$ On the contrary, the existing legal certainty does not reflect a sense of justice, let alone benefit the Indonesian people. Ironically, the law is not a tool of the

\footnotetext{
${ }^{22}$ Luthfi Widagdo Eddyono, “Quo Vadis Pancasila Sebagai Norma Konstitusi Yang Tidak Dapat Diubah,” Jurnal Konstitusi 16, no. 3 (2019): 585, https://doi.org/10.31078/jk1637.

23 Asshiddiqie, Konstitusi Keadilan Sosial: Serial Gagasan Konstitusi Sosial Negara Kesejahteraan Sosial Indonesia.

24 Muhardi Hasan and Estika Sari, "Hak Sipil Dan Politik," Demokrasi 4, no. 1 (2005): 93-101, http://ejournal.unp.ac.id/index.php/jd/article/view/1001.

${ }^{25}$ Sacipto Raharjo, Ilmu Hukum (Bandung: Citra Aditya Bhakti, 2006).
} 
authorities that can be dismantled according to interests, not back to the interests of the people's welfare.

A presidential system of government places the President as the centre of executive power and state power. This means that the President is the head of government (chief of the executive) and the head of state (chief of state) ${ }^{26}$ Reviewed normatively in the applicable laws and regulations, the President and Vice President have the privilege not to take leave outside the state's responsibility. The reason is that it is not regulated in any legislation so that the President and Vice President can leave their positions on the grounds of being temporarily absent, be it for political reasons during the campaign period or even for health reasons. This can be a legal loophole and a strong argument that the President and Vice President are not replaced as heads of state and heads of government. ${ }^{27}$

This weakness is felt to be a barrier to the enforcement of equality before the law against the incumbent President and Vice President candidates in the presidential election process. It can be a legal loophole for the problems that arise in the presidential election that has been described previously. However, suppose the President and Vice President do not allow them to leave their positions. Subsequently, it does not mean that professional ethics can be misused either openly or covertly by the incumbent Presidential and Vice President candidates. This is felt to be a repetition in every presidential election process. The incumbent can be favoured through a work program adjusted to the period approaching the presidential election.

The authority between the President and the Vice President may begin at the election and their authority's implementation. In general, the Vice President can exercise the authority and power as the President. This is because the President and the Vice President are one institution. When the President is unable to carry out his authority as head of state and head of government, the President is replaced by the Vice President. If the Vice President is vacant, the President may nominate a candidate that can be proposed to the MPR for election. Suppose the powers of the President and Vice President are vacant. In that case, those who can carry out their authority as stipulated in the 1945 Constitution are the Minister of Foreign Affairs, the Minister of Home Affairs and the Minister of Defense together. ${ }^{28}$

\section{Conclusion}

The authors provide the following conclusions from the author's analysis regarding the differences in leave arrangements outside of state responsibility for the candidates for President and Vice President and incumbent Regional Heads and Deputy Regional Heads based on the principle of equality before the law.

a. From the first problem, the author found differences regarding the arrangement of leaves outside the state's responsibility in the regulation of the presidential and post-conflict local elections. These differences are contained in two laws, namely Law Number 7 of 2017 concerning General Elections and Law Number 10 of 2016 concerning Regional Head Elections. By the differences given to the incumbent presidential and vicepresidential candidates, there is the potential for abuse of government facilities inherent in the positions of President and vice president. So the leave arrangements outside the state's responsibility have not been able to answer the problematic implementation of the presidential election. Then the arrangement of leaves outside the state's

\footnotetext{
26 Sudirman, "Kedudukan Presiden Dalam Sistem Pemerintahan Presidensial," Fakultas Hukum, Universitas Brawijaya, 2013, 1-27, http://hukum.studentjournal.ub.ac.id/index.php/hukum/article/view/526.

27 Thomas P Power, “Jokowi's Authoritarian Turn and Indonesia's Democratic Decline," Bulletin of Indonesian Economic Studies 54, no. 3 (2018): 307-38, https://doi.org/10.1080/00074918.2018.1549918.

${ }^{28}$ Zaki Ulya, "Kajian Yuridis Mekanisme Pengisian Jabatan Presiden Pasca Amandemen Undang-Undang Dasar Negara Republik Indonesia Tahun 1945," Jurnal Legislasi Indonesia 12, no. 4 (2015): 1-20, https://ejurnal.peraturan.go.id/index.php/jli/article/view/422/302.
} 
responsibility as stated in the Regional Head Election Law is deemed sufficient to reduce the problems that the author has described.

b. Regarding the application of the principle of equality before the law (equality before the law) in the difference in leave arrangements outside the state responsibility for the candidates for President and Vice President and candidates for Regional Head and Deputy Regional Head incumbent, the author concludes that from the difference between the two arrangements in the two laws. Different laws in the presidential and regional election processes are theoretically contrary to equality before the law based on Article 7 Paragraph (1) of the 1945 Constitution of the Republic of Indonesia as the legal basis for equality before the law principle's implementation.

c. This application is very concerned about equality in applying rights to citizens. In theory, it can be explained in the distributive justice indicator that regardless of the level of position, a citizen gets the same rights beyond his contribution. The rights of citizens given in this case are political, as also regulated in Article 28 Paragraph (3) of the 1945 Constitution of the Republic of Indonesia to vote and be elected without discrimination.

\section{Bibliography}

\section{A. Journal}

Aspinall, Edward, and Marcus Mietzner. "Indonesia's Democratic Paradox: Competitive Elections amidst Rising Illiberalism.” Bulletin of Indonesian Economic Studies 55, no. 3 (2019): 295-317. https://doi.org/10.1080/00074918.2019.1690412.

Buehler, Michael, and Ronnie Nataatmadja. "A Research Agenda for Studying Legislative Incumbent Turnover in New Democracies, Using Indonesia as a Case Study." South-East Asia Research 27, no. 3 (2019): 203-24. https://doi.org/10.1080/0967828X.2019.1642027.

Buehler, Michael, Ronnie Nataatmadja, and Iqra Anugrah. "Limitations to Subnational Authoritarianism: Indonesian Local Government Head Elections in Comparative Perspective." Regional \& Federal Studies 31, no. 3 (2021): 381-404. https://doi.org/10.1080/13597566.2021.1918388.

Eddyono, Luthfi Widagdo. "Quo Vadis Pancasila Sebagai Norma Konstitusi Yang Tidak Dapat Diubah.” Jurnal Konstitusi 16, no. 3 (2019): 585. https://doi.org/10.31078/jk1637.

Fitriyah. "MENINJAU ULANG SISTEM PILKADA LANGSUNG: MASUKAN UNTUK PILKADA LANGSUNG BERKUALITAS.” Politika: Jurnal Ilmu Politik 2, no. 1 (2013): 40-47. https://doi.org/10.14710/politika.2.1.2011.40-47.

Fossati, Diego. "A Tale of Three Cities: Electoral Accountability in Indonesian Local Politics." Journal of Contemporary Asia 48, no. 1 (2018): 23-49. https://doi.org/10.1080/00472336.2017.1376345.

Hasan, Muhardi, and Estika Sari. "Hak Sipil Dan Politik." Demokrasi 4, no. 1 (2005): 93-101. http://ejournal.unp.ac.id/index.php/jd/article/view/1001.

Khairazi, Fauzan. "Implementasi Demokrasi Dan Hak Asasi Manusia Di Indonesia." Inovatif: Jurnal Ilmu Hukum 8, no. 1 (2015): 72-94. https://onlinejournal.unja.ac.id/jimih/article/view/2194.

Latansa, Qonita Dina. "Konstitusionalitas Batasan Masa Jabatan Presiden Dan Wakil Presiden Di Indonesia." Jurist-Diction 2, no. 2 (2019): 595. https://doi.org/10.20473/jd.v2i2.14254.

Mahkamah Konstitusi Republik Indonesia. Naskah Komprehensif Perubahan UUD NRI 1945, (Buku IV Kekuasaan Pemerintah Negara Jilid 1. Revisi. Jakarta: Mahkamah Konstitusi Republik Indonesia, 2010. https://www.mkri.id/public/content/infoumum/naskahkomprehensif/pdf/naskah_Naskah Komprehensif Buku 4 Jilid 1.pdf. 
Muhammad Rudi Juanda. "Konstruksi Hukum Wajib Cuti Bagi Petahana Kepala Daerah Berdasarkan Putusan Mahkamah Konstitusi Nomor 60/PUU-XIV/2016." Jurnal Ilmu $\begin{array}{llllll}\text { Hukum Riau } & 8, & \text { no. } & 5 & \text { (2019): }\end{array}$ https://jih.ejournal.unri.ac.id/index.php/JIH/article/view/6038.

Nugraha, Al Fajar, and Atika Mulyandari. "Pilkada Langsung Dan Pilkada Tidak Langsung Dalam Perspektif Fikih Siyasah.” Mazahib: Jurnal Pemikiran Hukum Islam 15, no. 2 (2016): 208-37. https://doi.org/10.21093/mj.v15i2.630.

Power, Thomas P. "Jokowi's Authoritarian Turn and Indonesia's Democratic Decline." Bulletin of Indonesian Economic Studies 54, no. 3 (2018): 307-38. https://doi.org/10.1080/00074918.2018.1549918.

Prihatin, Eko Sabar. "Politik Hukum Otonomi Daerah Tentang Pemilukada." MasalahMasalah Hukum 43, no. 1 (2014): 49-56. https://doi.org/10.14710/mmh.43.1.2014.49-56.

Ridlwan, Zulkarnain. "Negara Hukum Indonesia Kebalikan Nachtwachterstaat." FIAT JUSTISIA:Jurnal Ilmu Hukum 5, no. 2 (2014): 141-52. https://doi.org/10.25041/fiatjustisia.v5no2.56.

Sihombing, Eka N.A.M. "Mendorong Pembentukan Peraturan Daerah Tentang Bantuan Hukum Di Provinsi Sumatera Utara." Jurnal Rechts Vinding: Media Pembinaan Hukum Nasional 2, no. 1 (2013): 81. https://doi.org/10.33331/rechtsvinding.v2i1.83.

Sudirman. "Kedudukan Presiden Dalam Sistem Pemerintahan Presidensial." Fakultas Hukum, Universitas Brawijaya, 2013, $1-27$. http://hukum.studentjournal.ub.ac.id/index.php/hukum/article/view/526.

Ulya, Zaki. "Kajian Yuridis Mekanisme Pengisian Jabatan Presiden Pasca Amandemen Undang-Undang Dasar Negara Republik Indonesia Tahun 1945." Jurnal Legislasi

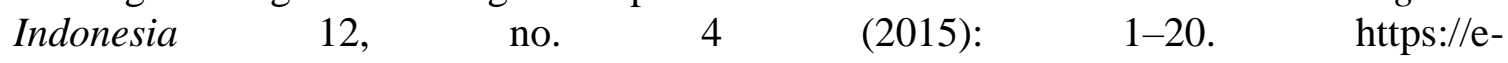
jurnal.peraturan.go.id/index.php/jli/article/view/422/302.

Wardana, Surya Kusuma. "Pemilihan Umum Sebagai Sarana Mewujudkan Pemerintahan Yang Bersih, Baik, Dan Berwibawa.” Seminar Nasional Hukum Universitas Negeri Semarang 4, no. $\quad 3 \quad$ (2018): https://doi.org/http://journal.unnes.ac.id/sju/index.php/snh/article/view/27098.

\section{B. Books}

Asshiddiqie, Jimly. Konstitusi Keadilan Sosial: Serial Gagasan Konstitusi Sosial Negara Kesejahteraan Sosial Indonesia. Jakarta: Penerbit Buku Kompas, 2018.

Budiyono, Budiyono, and Siti Khoiriah. Negara Hukum Dan Demokrasi. 1st ed. Bandar Lampung: Zam-Zam Towers, 2017.

Kaloh, J. Kepemimpinan Kepala Daerah: Pola Kegiatan, Kekuasaan, Dan Perilaku Kepala Daerah Dalam Pelaksanaan Otonomi Daerah. Jakarta: Sinar Grafika, 2009.

Raharjo, Sacipto. Ilmu Hukum. Bandung: Citra Aditya Bhakti, 2006.

Sadikin, Ali. Tantangan Demokrasi. Jakarta: Pustaka Sinar Harapan, 1995.

\section{Regulations}

1945 Constitution of the Republic of Indonesia.Undang-Undang Nomor 23 Tahun 2014

Law Number 1 of 2015Undang-Undang Nomor 2 Tahun 2015

Law Number 9 of 2015

Law Number 10 of 2016

Law Number 7 of 2017

Constitutional Court Decision No. 10/PUU-XVII/2019

Minister of Home Affairs Regulation No. 74 the Year 2016

Minister of Home Affairs Regulation No. 1 the Year 2018 


\section{Others}

KBBI. “Arti Petahana.” Lektur.id, 2019. https://lektur.id/arti-petahana.

."Petahana."Kemendikbud.go.id,2019. https://kbbi.kemendikbud.go.id/entri/Petahana. 